\title{
Impact of Tourism on Local Employment and Incomes in Three Selected Destinations: Case Studies of Sauraha, Nagarkot and Bhaktapur
}

\author{
- Dr. Kamal Banskota \\ kamalbanskota@gmail.com
}

\section{Introduction}

The tourism sector of Nepal has been an important sector for many decades in generating foreign exchange and employment in the country. It is a growing sector with huge potentials for investment and development (Afram and Del Poro 2012; Enterprise Europe Network, 2006). The natural beauty of the country, the diversity of its flora and fauna, important pilgrimage sites revered by the Hindus and the Buddhists and a haven for mountaineers have been the prime attracting factors for the growth in this sector, which has primarily been led by private enterprises. Although sometimes in the past other sectors such as the carpet and the garment industries have outstripped the tourism sector in terms of foreign exchange earnings and employment generation, time and again tourism has rebounded back to be an important sector in generating foreign exchange and employment in the country (Banskota and Sharma, 1993). However, Nepal's tourism sector has not performed well relative to other similar developing countries despite its endowment of a rich natural heritage (Bista, 2009).

Kathmandu has the country's only international airport and along with 7 UNESCO World Heritage Sites, it is also the main tourism hub of the nation. Virtually all tourists that visit Nepal have to fly into Kathmandu although a small number of Western and Indian visitors enter Nepal by the land route. In addition, because of the poor physical infrastructures throughout most of the country, despite the rich natural beauty, Kathmandu serves as a gateway to all destinations in Nepal. Destinations such as Pokhara and Chitwan that are easily accessible from Kathmandu are popular. Other destinations 
such as Sagarmatha National Park (world heritage site) and Annapurna Conservation Area are extremely popular with visitors interested in trekking and mountaineering. From a pilgrimage point of view Pashupatinath (Kathmandu) and Lumbini are the most popular destinations.

In 2011 visitors arrival to Nepal was all time highest (above 700,000 ) and so have the number of operators of all kinds increased in this sector (MoTCA, 2011). Most operators function in destinations that are relatively more accessible. Areas with poor infrastructures (for example Kosi Tappu and Dolpa) are obviously not favorable for the private sector to operate given that operating costs are exorbitant and not many visitors will be willing to pay for such destinations. Besides, existing levels of institutional and human resource capacities vary widely across destinations, and that the quality of facilities and the services provided below the expected standard even in the most popular destinations.

While there is some level of aggregate information on some characteristics of tourism in Nepal, such as the number visitors by important market segments, arrival months, nationality, airlines, availability of hotels beds in some cities, number of operators (guide, trekking and travel agencies, tour operators), foreign currency generated by this sector etc., few studies exist on the status of tourism in different destinations. For example, it is well known that tourism generates foreign exchange, but how much income do local people earn from tourism in destination such as Sauraha? What effect does seasonality have on employment of local people? How are local people benefiting from the sale of agricultural products to the tourism sector in their areas? What is the status of female employment in the local tourism sector and how do the wages/salaries vary across males and females employee? These and many other issues related to sustainable pro-poor development are not welldocumented in the different destinations of Nepal, which is essential for making any kind of informed decisions to advocate/formulate specific policies to promote tourism. Sustainable pro-poor development studies at different 
destinations are useful to develop a comprehensive knowledgebase of this sector to address important questions on how local people can benefit from tourism in their areas; how tourism receipts are spread across different areas; how tourism is impacting the local economy etc. (Ashley et al., 2007; Frechtling, 2006 \& 2011; Wang \& Davidson, 2006).

The future growth of tourism will continue to be centered in the above destinations. Many areas in Nepal have high potentials for tourism development but will require development of infrastructures (roads, bridges, airports, accommodation facilities etc.) and human resources to manage the tourism industry. The country does not have any concrete plan for such a planned development of the tourism sector. Recently, Nepal Tourism Board (NTB) has compiled a "Tourism Product of Nepal" as a promotional material on the occasion of "Visit Nepal Tourism Year 2011." The Government of Nepal announced a Tourism Policy about 4 years ago. In addition, a Tourism 2020 Vision was developed in which it was stated to attract 2 million visitors by 2020 (MoTCA, 2009). Its strategy includes, among others, improving livelihoods and spreading benefits at the grassroots level and expanding products and attracting new investment. The Great Himalayan Trail is another concept that is being jointly studied in detail by the Government and SNV-Nepal. Thus, there appear to be different ideas for a concrete action plan, but the sense of what will benefit the industry and its stakeholders across the country is absent.

Sauraha, Nagarkot and Bhaktapur are the three destinations that have been selected for this study because they are located close to Kathamndu, and at the same time give some flavor of different types of tourist visit motivations. Bhaktapur is purely a heritage site. Nagarkot is famous for its mountain views and where overnight stay is necessary and Sauraha combines many different types of wilderness experiences. Our ultimate object is to be able to derive tourism expenditure impacts and multipliers and other policy parameters. It is hoped that by building these micro level understandings of tourist expenditures, and service 
providers, the study will help us come up with better assessment of the diversity of the impacts of this important economic activity in Nepal.

\section{Study Objectives}

Research in Nepal's tourism sector is not growing and information on the demand and supply sides of tourism is poor (Bista, 2009). Using primary data collected from accommodation establishments, this study focuses on three of the more accessible tourism destinations from Kathmandu to understand how the tourism sector is generating employment and income in the local areas. The main objective of this study is to "assess some direct impacts of tourism in the local economy of selected destinations." In particular the paper highlights the size of tourism and its impact on the three destinations.

The specific questions addressed here are:

1. How much employment (male and female) is tourism generating in the selected destination?

2. How much do local people benefit from the sales of agricultural products to the local tourism sector?

3. How much income is generated by the tourism sector and how much of it is locally retained?

\section{Study Sites}

Three destinations have been selected for this study namely: Sauraha, Nagarkot and Bhaktapur. All the three destinations are reputed for their own specific comparative advantages. Bhaktapur - the "city of devotees" is a UNESCO World Heritage Site and is popular for its fine monuments, cultural heritage and temples. As a result, Bhaktapur is a day-time destination. However, there are accommodation establishments here for visitors to stay overnight. A small number of visitors stay overnight during the peak season. 
Nagarkot is located about $15 \mathrm{~km}$ and $23 \mathrm{~km}$ east of Bhaktapur and Kathmandu respectively on top of a hill at an elevation of about 2,200 meters. The comparative advantage of this destination is "the magnificent view of the sunrise over the Central Himalaya." On a clear morning the experience is breathtaking.

Sauraha is adjacent to Nepal's first national park, namely the Chitwan National Park established in 1973. Sauraha has grown over time from a small Tharu Village into a little tourism town with different types of tourism establishments. The comparative advantage of this destination is to visit the Park and to see "protected Royal Bengal Tiger and the Asian One-Horned Rhino," both endangered species.

\section{Methodology}

Three students who were funded from this project collected primary information from the field based on structured questionnaire. The School of Arts, Kathmandu University (SoAKU), coordinated all the studies. There were several rounds of meeting at SoAKU to select the research topic and sites. After selecting the topic, important issues to be addressed were identified and a set of questionnaires were then prepared and pre-tested. A second round discussion meeting was again held at SoAKU to review the results of the pre-test and to finalize the questionnaires.

It was decided that given the time limitation and the nature of the research study it was sufficient to focus on two important supply components of tourism namely hotels/restaurants and shops that catered to tourists. To understand some aspects of tourist demand, it was also decided to develop a simple and short questionnaire to administer to visitors. The three students have analyzed the respective topics in their research studies as part of their Masters of Arts degree in Development Studies. This paper deals with only the accommodation establishments and relies totally on the data collected by the students. 
After the data was all collected, it was computerized using Excel and SPSS programmes. Data entry errors were crosschecked using simple descriptive statistics and tracing errors to the questionnaire. SPSS was utilized to conduct the analysis.

\section{Limitations of the Study}

Only the accommodation establishments have been analyzed and hence the study is unable to provide full picture of the impacts of the tourism sector in the local areas. The accommodation establishments are the largest group of stakeholders in Sauraha and Nagarkot but not in Bhaktapur, which is primarily a day-time destination given its proximity to Kathmandu. Hence in the case of Bhaktapur the estimated benefits are expected to be smaller than the full benefits of tourism. In the other two destinations the estimated benefits originating from the accommodation establishments are the major benefits resulting from tourism. However, it is not possible to say how much these benefits are as percentage of the total tourism benefits. To address this question will require a more comprehensive study and will be a useful future exercise to undertake for research by SoAKU and NTB.

\section{Results}

\section{Structure of Accommodation}

This section presents the structure of accommodations in the three study destinations namely Sauraha, Nagarkot and Bhaktapur. The topic covers the types of establishments as they are registered with the government, their years in operation, their room and bed capacities and the facilities they provide to visitors. Accommodation facilities play an important role in attracting visitors and are also a prime source of employment and income to people (Bista, 2009).

The study surveyed 73, 32 and 16 accommodation establishments in Sauraha, Nagarkot and Bhaktapur, respectively, and was visually a census of the establishments in 
these destinations. Of the 121 different establishments surveyed 60\% were in Sauraha, while Nagarkot had $26 \%$ and Bhaktapur only about half that of Nagarkot. Clearly, Bhaktapur does not appear to be an overnight stay destination for tourists and most tourists who visit Bhaktapur prefer to return and stay overnight in Kathmandu. Likewise, of all the establishments surveyed $38 \%$ had registered as hotel, $26 \%$ as resort, $21 \%$ as guest house and $15 \%$ as lodge. Notice that no establishments in Bhaktapur had registered as resort and there were likewise no guest houses registered in Nagarkot (Table 1).

Table 1: Distribution of Establishments by Type and Destinations

\begin{tabular}{|l|l|l|l|l|l|l|l|l|}
\hline \multirow{2}{*}{$\begin{array}{l}\text { Type of } \\
\text { Establishment }\end{array}$} & \multicolumn{2}{|l|}{ Sauraha } & \multicolumn{2}{l|}{ Nagarkot } & \multicolumn{2}{l|}{ Bhaktapur } & \multicolumn{2}{l|}{ Total } \\
\cline { 2 - 9 } & Number & $\%$ & Number & $\%$ & Number & $\%$ & Number & $\%$ \\
\hline Hotels & 28 & 61 & 16 & 35 & 2 & 4 & 46 & 38 \\
\hline Resorts & 16 & 52 & 15 & 48 & 0 & 0 & 31 & 26 \\
\hline Lodges & 15 & 83 & 1 & 6 & 2 & 11 & 18 & 15 \\
\hline Guest House & 14 & 54 & 0 & 0 & 12 & 46 & 26 & 21 \\
\hline Total & 73 & 60 & 32 & 26 & 16 & 13 & 121 & 100 \\
\hline
\end{tabular}

In Table 2 below the mean years of operation of the different accommodation establishments are provided. The highest mean years of operation (17 years) is seen to be that of the hotel establishments in Nagarkot. There was one resort in Nagarkot that reported to have been in operation for 36 years. Also the mean years of operation of the establishments in Nagarkot (14.5 years) are higher than in Sauraha (9.33 years) and Bhaktapur (10.67 years). It may be observed from the table that in all the three locations, lodges as a group are the oldest establishments and have been operating on an average for 13.67 years. Hotels are relatively new establishments ( 5.5 years) in Bhaktapur but guest houses have been in operation for the longest period (1067 years) relative to either Sauraha (9.71 years). Notice that there were guest houses reported in Nagarkot. Likewise there were no resorts reported in Bhaktapur. Bhaktapur is popular for cultural tourism and is a short distance away from Kathmandu 
and most tourists who visit this city prefer to return to Kathmandu for the night stay. On the other hand, Nagarkot is popular for the sunrise on the Himalaya, which is not visible from either Bhaktapur or Kathmandu. Finally, Sauraha is a wildlife tourism destination and is at least a day's drive down south from Kathmandu and requires a few days of night stop.

Table 2: Mean Years of Operation by Type of Establishments and Destinations

\begin{tabular}{|l|l|l|l|l|l|l|}
\hline \multicolumn{2}{|c|}{ Destinations } & Hotels & Resorts & Lodges & $\begin{array}{l}\text { Guest } \\
\text { Houses }\end{array}$ & Total \\
\hline \multirow{3}{*}{ Sauraha } & Mean & 7.32 & 8 & 14.13 & 9.71 & 9.33 \\
\cline { 2 - 7 } & $\begin{array}{l}\text { Std. } \\
\text { Deviation }\end{array}$ & 7.71 & 5.1 & 10.37 & 7.66 & 8.12 \\
\hline \multirow{3}{*}{ Nagarkot } & Mean & 17.06 & 11.73 & 15 & na & 14.5 \\
\cline { 2 - 7 } & $\begin{array}{l}\text { Std. } \\
\text { Deviation }\end{array}$ & 8.39 & 9.42 & na & na & 9.02 \\
\hline \multirow{3}{*}{ Bhaktapur } & Mean & 5.5 & na & 9.5 & 10.67 & 9.88 \\
\cline { 2 - 7 } & $\begin{array}{l}\text { Std. } \\
\text { Deviation }\end{array}$ & 6.36 & na & 7.78 & 7.91 & 7.45 \\
\hline \multirow{2}{*}{ Total } & Mean & 10.63 & 9.81 & 13.67 & 10.15 & 10.77 \\
\cline { 2 - 7 } & $\begin{array}{l}\text { Std. } \\
\text { Deviation }\end{array}$ & 9.15 & 7.62 & 9.72 & 7.63 & 8.52 \\
\hline
\end{tabular}

na: not applicable due to insufficient observation in the cell.

In terms of bed capacities Sauraha and Nagarkot have the highest bed capacities (around 48), while Bhaktapur's bed capacity is almost half (27). But in Nagarkot bed capacity varies considerably relative to the other two years as observed by the standard deviation (49) which is higher than mean bed capacity (48). Hotels have the highest capacity in terms of beds (47) and guest houses have the lowest (22). Table 3 also provides further information of the capacity of the establishments in terms of rooms. On an average, in all destinations across all accommodation establishments, the ratio of beds per room is around 2. What may also be observed from Table 3 is that across all accommodation establishments almost all rooms have attached toilets and running hot water. It reveals that these basic facilities are essential to attract visitors and to be competitive in the tourism industry. 
Table 3: Capacity and Facilities of Accommodation Establishments

\begin{tabular}{|c|c|c|c|c|c|c|c|c|c|}
\hline \multirow[t]{2}{*}{$\begin{array}{l}\text { Type of } \\
\text { Establishments }\end{array}$} & \multirow[t]{2}{*}{ Destinations } & \multicolumn{2}{|c|}{ Bed Capacity } & \multicolumn{2}{|c|}{$\begin{array}{l}\text { Room } \\
\text { Capacity }\end{array}$} & \multicolumn{2}{|c|}{$\begin{array}{l}\text { Number of } \\
\text { Rooms with } \\
\text { attached bath } \\
\text { rooms }\end{array}$} & \multicolumn{2}{|c|}{$\begin{array}{l}\text { Number of } \\
\text { rooms with hot } \\
\text { water service }\end{array}$} \\
\hline & & Mean & $\begin{array}{l}\text { St. } \\
\text { Dev. }\end{array}$ & Mean & $\begin{array}{l}\text { St. } \\
\text { Dev. }\end{array}$ & Mean & $\begin{array}{l}\text { St. } \\
\text { Dev. }\end{array}$ & Mean & $\begin{array}{l}\text { St. } \\
\text { Dev. }\end{array}$ \\
\hline \multirow{4}{*}{ Hotels } & Sauraha & 48.50 & 28.16 & 19.39 & 9.73 & 19.00 & 9.94 & 19.00 & 9.94 \\
\hline & Nagarkot & 47.63 & 49.34 & 21.75 & 18.50 & 21.56 & 18.67 & 20.00 & 19.67 \\
\hline & Bhaktapur & 27.00 & 4.24 & 17.00 & 2.83 & 12.50 & 3.54 & 12.50 & 3.54 \\
\hline & Total & 47.26 & 36.15 & 20.11 & 13.15 & 19.61 & 13.40 & 19.07 & 13.81 \\
\hline \multirow{3}{*}{ Resorts } & Sauraha & 40.56 & 21.29 & 15.88 & 6.76 & 15.88 & 6.76 & 15.88 & 6.76 \\
\hline & Nagarkot & 31.33 & 19.03 & 15.13 & 8.55 & 14.53 & 8.83 & 14.80 & 8.78 \\
\hline & Total & 36.10 & 20.43 & 15.52 & 7.56 & 15.23 & 7.73 & 15.35 & 7.69 \\
\hline \multirow{4}{*}{ Lodges } & Sauraha & 34.00 & 19.30 & 12.60 & 6.83 & 12.20 & 7.00 & 12.20 & 7.00 \\
\hline & Nagarkot* & 56.00 & - & 28.00 & - & 28.00 & - & 28.00 & - \\
\hline & Bhaktapur & 22.50 & 3.54 & 10.00 & 5.66 & 7.00 & 4.24 & 7.00 & 4.24 \\
\hline & Total & 33.94 & 18.75 & 13.17 & 7.40 & 12.50 & 7.69 & 12.50 & 7.69 \\
\hline \multirow{3}{*}{ Guest Houses } & Sauraha & 22.07 & 17.94 & 10.64 & 7.57 & 9.71 & 8.15 & 9.71 & 8.15 \\
\hline & Bhaktapur & 21.75 & 19.41 & 10.83 & 8.21 & 9.75 & 8.85 & 9.75 & 8.85 \\
\hline & Total & 21.92 & 18.25 & 10.73 & 7.71 & 9.73 & 8.31 & 9.73 & 8.31 \\
\hline \multirow{4}{*}{ Total } & Sauraha & 38.71 & 24.88 & 15.55 & 8.76 & 15.14 & 9.03 & 15.14 & 9.03 \\
\hline & Nagarkot & 40.25 & 37.63 & 18.84 & 14.57 & 18.47 & 14.81 & 17.81 & 15.24 \\
\hline & Bhaktapur & 22.50 & 16.77 & 11.50 & 7.54 & 9.75 & 7.84 & 9.75 & 7.84 \\
\hline & Total & 36.98 & 28.37 & 15.88 & 10.63 & 15.31 & 10.96 & 15.13 & 11.06 \\
\hline
\end{tabular}

na: not applicable due to insufficient observation in the cell.

The accommodation establishments were asked about the different types of facilities they offered to their visitors. The different types of facilities identified were the following: internet, cable TV, vehicle pick up and drop, cultural show and music, camping and campfire, guides, newspapers, conference halls and others.

Table 4: Facilities Provided by Accommodation Establishment

\begin{tabular}{|l|l|l|l|l|l|l|}
\hline & & Hotel & Resort & Lodge & $\begin{array}{l}\text { Guest } \\
\text { House }\end{array}$ & Total \\
\hline \multirow{3}{*}{ Sauraha } & Mean & 7.86 & 8.38 & 7.80 & 5.86 & 7.58 \\
\cline { 2 - 7 } & $\begin{array}{l}\text { Std. } \\
\text { Deviation }\end{array}$ & 1.53 & 0.72 & 1.42 & 3.51 & 2.09 \\
\hline \multirow{3}{*}{ Nagarkot } & Mean & 6.44 & 5.87 & 6.00 & na & 6.16 \\
\cline { 2 - 7 } & $\begin{array}{l}\text { Std. } \\
\text { Deviation }\end{array}$ & 3.03 & 3.14 & na & na & 3.00 \\
\hline \multirow{3}{*}{ Bhaktapur } & Mean & 7.50 & na & 8.00 & 5.58 & 6.13 \\
\cline { 2 - 7 } & $\begin{array}{l}\text { Std. } \\
\text { Deviation }\end{array}$ & 0.71 & na & 0.00 & 3.68 & 3.30 \\
\hline \multirow{3}{*}{ Total } & Mean & 7.35 & 7.16 & 7.72 & 5.73 & 7.01 \\
\cline { 2 - 7 } & $\begin{array}{l}\text { Std. } \\
\text { Deviation }\end{array}$ & 2.22 & 2.54 & 1.36 & 3.52 & 2.61 \\
\hline
\end{tabular}

na: not applicable due to insufficient observation in the cell. 
While guest houses provide the lowest number of facilities (5.7), resorts in Bhaktapur and Sauraha are seen to provide almost the full range of facilities listed above. But on an average, most of the accommodation establishments appear to provide at least 6 of the facilities, indicating the growing competitive nature of the industry across the 3 destinations.

\section{Seasonality}

Not all months of the year are favorable months to the accommodation establishments in terms of tourism. Especially the rainy season and a short period in winter are considered to be the slack seasons when the number of visitors to Nepal as well as the different destinations falls sharply. Visitors were asked to provide information on when they considered the tourism season to be peak and slack periods based on their experience. The results are provided in Table 5 for the different destinations. What emerges from the results is that Asar and Shrawn months, which also coincide with the monsoon period and when the Nepali farmers are extremely busy with paddy plantation, are two main slack months in tourism. Bhadra also may be considered a slack month based on the information provided by the respondents. Another month when there is modest dip in the flow of tourism is in Magh, especially in Nagarkot (where it gets cold) and Bhaktapur also experiences a decline. Sauraha attracts visitors as it is a relatively warmer destination than the other two in the month of Magh and hence Sauraha does not seem to experience much slackness in tourism like the other two destinations (Table 5).

Table 5: Percentage of Accommodation Establishments Reporting Tourism Peak and Slack

\begin{tabular}{|c|c|c|c|c|c|c|c|c|c|c|c|c|}
\hline \multicolumn{13}{|c|}{ Months } \\
\hline 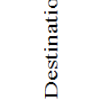 & 离 & 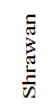 & $\begin{array}{l}\frac{\pi}{\frac{\pi}{\tau}} \\
\frac{\pi}{M}\end{array}$ & 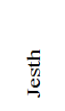 & 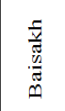 & 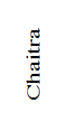 & $\begin{array}{l}\frac{\tilde{w}}{\mathrm{w}} \\
\overline{0} \\
\tilde{L}\end{array}$ & 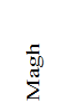 & $\begin{array}{l}\Xi_{0} \\
\frac{000}{\pi} \\
\tilde{I}\end{array}$ & 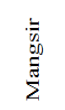 & $\sum_{2}^{\frac{5}{2}}$ & 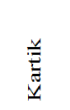 \\
\hline Sauraha & 5.00 & 7.00 & 12.00 & 30.00 & 37.00 & 63.00 & 77.00 & 79.00 & 86.00 & 97.00 & 98.00 & 100.00 \\
\hline Nagarkot & 0.00 & 0.00 & 6.20 & 12.50 & 25.00 & 37.50 & 78.10 & 0.90 & 46.90 & 96.90 & 87.50 & 93.80 \\
\hline Bhaktapur & 0.00 & 0.00 & 0.00 & 0.00 & 31.30 & 37.50 & 31.30 & 12.50 & 25.00 & 81.30 & 93.80 & 100.00 \\
\hline
\end{tabular}




\section{Occupancy of the Accommodation Establishments}

Occupancy is defined as the proportion of the number of beds actually occupied by the tourists relative to total number of beds available (potential) in a year (365 days). This detailed information was not available and in order to obtain an idea on occupancy, the respondents were given a percentage range and asked to identify in which range they best judged their beds were occupied during the peak and slack seasons. This information was then multiplied by the number of beds in each establishment to derive the actual days the beds were occupied. The actual occupancy days was then divided by the potential occupancy, to obtain the occupancy rate in each season.

The overall mean occupancy rate in the peak season is about $90 \%$, while the slack season rate is less than half this rate (41\%), with Bhaktapur registering the lowest slack season rate (35\%). Within the hotel establishments, occupancy rates during both peak (89\%) and slack (43\%) are highest in Sauraha. For resorts, Nagarkot reports the highest occupancy rate for the peak season (94\%), but this rate drops to 39\% during the slack season. Lodges in both Sauraha and Bhaktapur report about the same highest occupancy rate (93\%), but during the slack season, the occupancy rate in Bhaktapur drops significantly low to just about $15 \%$. The occupancy rates for the guest houses in all destinations show marginal variation across the seasons. During the slack season the occupancy rate among the guest houses drops significantly to about $39 \%$ across all destinations (Table 6). What is noticeable from the last column of Table 6 is that the occupancy rate during the slack season drops more than half relative to the peak season occupancy rate across all establishments and destinations. Note in Bhaktapur this drop is significant and slack season occupancy is only about $15 \%$ that of the peak season. 
Table 6: Mean Occupancy Rate of the Establishment by Destinations during Peak and Slack Seasons

\begin{tabular}{|c|c|c|c|c|}
\hline \multirow[b]{2}{*}{$\begin{array}{l}\text { Type of } \\
\text { Establishment }\end{array}$} & \multirow[b]{2}{*}{ Destination } & \multicolumn{2}{|c|}{$\begin{array}{l}\text { Occupancy Rate } \\
(\%)\end{array}$} & \multirow{2}{*}{$\begin{array}{l}\text { Occupancy } \\
\text { Ratio } \\
\text { Slack/Peak } \\
\text { Season }\end{array}$} \\
\hline & & $\begin{array}{l}\text { Peak } \\
\text { Season }\end{array}$ & $\begin{array}{l}\text { Slack } \\
\text { Seaso } \\
\mathrm{n}\end{array}$ & \\
\hline \multirow{4}{*}{ Hotels } & Sauraha & 89.32 & 43.18 & 0.48 \\
\hline & Nagarkot & 81.06 & 39.56 & 0.49 \\
\hline & Bhaktapur & 87.00 & 26.50 & 0.30 \\
\hline & Total & 86.35 & 41.20 & 0.48 \\
\hline \multirow{3}{*}{ Resorts } & Sauraha & 92.69 & 44.63 & 0.48 \\
\hline & Nagarkot & 94.27 & 39.40 & 0.42 \\
\hline & Total & 93.45 & 42.10 & 0.45 \\
\hline \multirow{4}{*}{ Lodges } & Sauraha & 93.40 & 33.20 & 0.36 \\
\hline & Nagarkot & 87.00 & 38.00 & 0.44 \\
\hline & Bhaktapur & 93.50 & 15.00 & 0.16 \\
\hline & Total & 93.06 & 31.44 & 0.34 \\
\hline \multirow{3}{*}{ Guest Houses } & Sauraha & 86.64 & 39.29 & 0.45 \\
\hline & Bhaktapur & 90.67 & 39.08 & 0.43 \\
\hline & Total & 88.50 & 39.19 & 0.44 \\
\hline \multirow{4}{*}{ Total } & Sauraha & 90.38 & 40.70 & 0.45 \\
\hline & Nagarkot & 87.44 & 39.44 & 0.45 \\
\hline & Bhaktapur & 90.56 & 34.50 & 0.38 \\
\hline & Total & 89.63 & 39.55 & 0.44 \\
\hline
\end{tabular}

\section{Tariff Structure and Variations}

The tariff rate is the most important instrument which establishments can use to influence or allure visitors to their accommodations. Facilities provided by the establishments are also important, but usually the tariff rates already reflect the cost of the facilities provided. Establishments often quote a standard rate - which often reflects the maximum rate. But depending on the demand (for accommodation) situation, they lower their tariff rates within some margin to attract visitors. In addition, during the slack season when occupancy rates are low, 
the tariff rates become an important instrument to attract visitors. Tariff rates may be lowered to rates that are just sufficient to cover the variable/running costs of the establishments. This section examines some of these issues related to tariff rates and its variation across the establishments and destinations.

The previous section has already argued that occupancy rates fall significantly low during the slack season relative to the peak season. Thus during the slack season a rational entrepreneur would reduce (temporary) staff, all possible operating costs and also reduce the slack season tariff rate to raise revenues that may help it cover the slack season variable costs. Respondents were first asked if they reduced the tariff rate during the slack season relative to the peak season and the results are provided in Table 7.

Overall, as many as $65 \%$ of the establishment reported they reduce tariff during the slack season. In Bhaktapur this percentage was as high as $88 \%$, while in Sauraha only $58 \%$ reported they reduced tariffs. Guest houses appear to have the greatest difficulty during the slack seasons and as high as $85 \%$ report reducing their tariff rates. This is followed by the hotels and $52 \%$ report reducing tariff rates. Finally $68 \%$ and $67 \%$ of the resorts and lodges report tariff reduction during the slack season.

Across the destinations all lodges (100\% each) in Nagarkot and Bhaktapur reported they reduce their tariff rates (Table 7). A large majority of the guest houses (83\%) in Bhaktapur also reported reducing tariff rates in the slack season. Hotels in Sauraha appear to do the best as only 39\% reported to have reduced tariff rates in the slack season. Overall the results indicate that guest houses have a relatively greater problem of occupancy in the slack season and, as a result, majority (84\%) of the guest houses reduce their tariff rates. On the other hand, the hotels face a relatively lesser problem since only $52 \%$ of them reported to reduce tariff rates in the slack season. 
Table 7: Percentage of Establishments That Reported Reducing Tariff Rates in the Slack Season

\begin{tabular}{|l|l|l|l|l|}
\hline $\begin{array}{l}\text { Type of } \\
\text { Establishment }\end{array}$ & $\begin{array}{l}\text { Sauraha } \\
(\%)\end{array}$ & $\begin{array}{l}\text { Nagarkot } \\
(\%)\end{array}$ & $\begin{array}{l}\text { Bhaktapur } \\
(\%)\end{array}$ & $\begin{array}{l}\text { Total } \\
(\%)\end{array}$ \\
\hline Hotels & 39.29 & 68.75 & 100.00 & 52.17 \\
\hline Resorts & 62.50 & 73.33 & na & 67.74 \\
\hline Lodges & 60.00 & 100.00 & 100.00 & 66.67 \\
\hline Guest Houses & 85.71 & na & 83.33 & 84.62 \\
\hline Total & 57.53 & 71.88 & 87.50 & 65.29 \\
\hline
\end{tabular}

na- Not applicable

Given the different tariff rates charged by the establishments across the destinations, a weighted average rate for the peak and slack season was calculated. Weighted rates are calculated because the establishments have different types of room to offer to the visitors, namely rooms with single, double, multiple and twin beds. Some establishments also offer suites. Since the number of suites was almost negligible, they have been included in the multiple bed category rooms. Table 8 provides an idea of the tariff rates across the establishments and destinations and how they vary. The table also provides the percentage reduction in tariff made by the establishments in each destination during the slack season relative to the peak season. The reductions are extremely high. If this is really the case, then it indicates that the establishments can operate their businesses at a fairly low operating cost during the slack season. During conversation with the respondents, not one actually reported to be operating at a loss. The results suggest that the establishments in all the destinations make normal profits.

It is interesting at this point to determine if the variations observed are statistically significant. Statistically speaking the null hypothesis would be to assume that there are no differences in the tariff rates across the establishments. Likewise, we also tested the same null hypothesis across the accommodation establishments. One way analysis of variance results quickly provides an answer to this question. The calculated F-values of 
the peak season tariff rates were highly significant across establishments and destination (13.42 and 6.14). The same, however, can be said of the slack season tariff rates. While the F-test indicates a significant difference in the slack season tariff rates across establishments (4.10), the difference across destinations was insignificant (.22). These results indicate that during the slack season the tariff reduction across the destination is not an effective instrument to allure visitors to their establishments. The case is however different across establishments even in the slack season and also true across both establishments and destinations in the peak season. The establishments across the destination price their beds significantly differently to allure visitors so as to maximize profits. Table 8 provides the tariff structure.

\begin{tabular}{|c|c|c|c|c|c|}
\hline \multirow{2}{*}{$\begin{array}{l}\text { Type } \\
\text { of } \\
\text { Establishment }\end{array}$} & \multirow{2}{*}{ Season } & \multicolumn{4}{|c|}{ Tariff Rate (Rs./bed/night) } \\
\hline & & Sauraha & Nagarkot & Bhaktapur & Average \\
\hline \multirow{2}{*}{ Hotels } & Peak & 2134 & 3067 & 3815 & 2532 \\
\hline & Slack & 288 & 800 & 1209 & 506 \\
\hline \multirow{2}{*}{ Resorts } & Peak & 1830 & 3821 & na & 2793 \\
\hline & Slack & 354 & 627 & na & 486 \\
\hline \multirow{2}{*}{ Lodges } & Peak & 1482 & 5009 & 3229 & 1872 \\
\hline & Slack & 329 & 1746 & 781 & 457 \\
\hline \multirow{2}{*}{ Guest Houses } & Peak & 1009 & na & 1010 & 1009 \\
\hline & Slack & 368 & na & 363 & 366 \\
\hline \multirow{2}{*}{ Total } & Peak & 1718 & 3481 & 1638 & 2173 \\
\hline & Slack & 326 & 748 & 521 & 464 \\
\hline
\end{tabular}

\section{Impact of the Accommodation Establishments on Employment}

Information was collected on the number staff (males and females) hired by the establishments and the respective positions or salaries each staff was receiving. During the slack season there is a possibly to lay off staff and hence information was also collected on the staff retained during this season. The sum of employment in the peak and slack seasons was considered to be the annual employment in the establishments. The staffs working as permanent employees were those who would not lose their jobs during the slack season. It was revealed that most of the establishments requested their staffs to 
take their annual leave during the slack season when the work load in the industry is at its lowest and this way jobs are not lost permanently and also some variable costs can be reduced.

Obviously, large establishments with 51 or more beds hire more staff than either the medium or small size establishments. The average permanent employment per establishment is 11 and the variation is also fairly uniform across the establishments (standard deviation 10.4) indicating that permanent employment is directly proportional to the size of establishments. It is interesting to note that this proportional relationship is fairly linear in that medium-sized establishments hire about twice as many male staffs (9.44) as small establishments (4) and the large establishments hire male staffs (20.11) about twice as many male staffs as the medium establishments. In the case of the female staffs a similar employment relation is also observed, but the difference is narrower.

The tourism industry in the destinations covered is dominated by male staffs (average 9.3), which is over five times higher than female employment (average 1.77). It is interesting to note that generally as the size of the establishment increases, so does female employment, but in all establishments the percentage females employed relative to men is poor as shown in the last column of Table 9. In the establishments, in Bhaktapur there is a moderate deviation from the trend as seen in Table 9, where female permanent employment is relatively higher (about 32\%) than across establishments and destinations.

During the peak season when the occupancy rates across the destinations and establishments increases there is possibility that there will be an increase in the demand for more staff. 
Table 9: Status of Permanent Employment by Destinations and Size of Establishments

\begin{tabular}{|c|c|c|c|c|c|c|c|c|}
\hline \multirow{2}{*}{\multicolumn{2}{|c|}{ Establishment Details }} & \multicolumn{6}{|c|}{$\begin{array}{l}\text { Permanent Staff Temporary Staff per } \\
\text { Establishment }\end{array}$} & \multirow{4}{*}{$\begin{array}{l}\text { \% Male } \\
\text { Employed } \\
79\end{array}$} \\
\hline & & \multicolumn{2}{|c|}{ Male } & \multicolumn{2}{|c|}{ Female } & \multicolumn{2}{|c|}{ Total } & \\
\hline & & Mean & $\begin{array}{l}\text { Std. } \\
\text { Dev }\end{array}$ & Mean & $\begin{array}{l}\text { Std. } \\
\text { Dev }\end{array}$ & Mean & $\begin{array}{l}\text { Std. } \\
\text { Dev }\end{array}$ & \\
\hline \multirow{4}{*}{ Sauraha } & $\begin{array}{l}\text { Small }<25 \\
\text { beds }\end{array}$ & 4.10 & 2.72 & 1.06 & 1.12 & 5.16 & 2.81 & \\
\hline & $\begin{array}{l}\text { Medium } \\
26-50 \text { beds }\end{array}$ & 9.17 & 4.88 & 1.54 & 1.25 & 10.71 & 5.40 & 86 \\
\hline & $\begin{array}{l}\text { Large } 51+ \\
\text { beds }\end{array}$ & 17.39 & 8.79 & 3.22 & 2.41 & 20.61 & 10.47 & 84 \\
\hline & Total & 9.04 & 7.54 & 1.75 & 1.78 & 10.79 & 8.73 & 84 \\
\hline \multirow{4}{*}{ Nagarkot } & $\begin{array}{l}\text { Small }<25 \\
\text { beds }\end{array}$ & 5.33 & 1.50 & 1.13 & 0.74 & 6.47 & 1.64 & 82 \\
\hline & $\begin{array}{l}\text { Medium } \\
26-50 \text { beds }\end{array}$ & 10.67 & 5.43 & 1.00 & 0.87 & 11.67 & 6.06 & 91 \\
\hline & $\begin{array}{l}\text { Large } 51+ \\
\text { beds }\end{array}$ & 27.63 & 18.65 & 3.75 & 1.49 & 31.38 & 19.86 & $\mathbf{s s}$ \\
\hline & Total & 12.41 & 13.11 & 1.75 & 1.52 & 14.16 & 14.38 & 88 \\
\hline \multirow{4}{*}{ Bhaktapur } & $\begin{array}{l}\text { Small }<25 \\
\text { beds }\end{array}$ & 2.50 & 1.24 & 1.42 & 1.24 & 3.92 & 2.31 & 64 \\
\hline & $\begin{array}{l}\text { Medium } \\
26-50 \text { beds }\end{array}$ & 8.00 & $\mathbf{5 . 5 7}$ & 2.33 & 0.58 & 10.33 & 6.03 & 77 \\
\hline & $\begin{array}{l}\text { Large } 51+ \\
\text { beds }\end{array}$ & 9.00 & na & 6.00 & na & 15.00 & na & 60 \\
\hline & Total & 3.94 & 3.45 & 1.88 & 1.59 & 5.81 & 4.62 & 68 \\
\hline \multirow{4}{*}{ Total } & $\begin{array}{l}\text { Small }<25 \\
\text { beds }\end{array}$ & 4.09 & 2.39 & 1.16 & 1.06 & 5.24 & 2.57 & 78 \\
\hline & $\begin{array}{l}\text { Medium } \\
26-50 \text { beds }\end{array}$ & 9.44 & 4.98 & 1.47 & 1.16 & 10.92 & 5.46 & 87 \\
\hline & $\begin{array}{l}\text { Large } 51+ \\
\text { beds }\end{array}$ & 20.11 & 13.09 & 3.48 & 2.17 & 23.59 & 14.33 & 85 \\
\hline & Total & 9.26 & 9.30 & 1.77 & 1.68 & 11.02 & 10.40 & 84 \\
\hline
\end{tabular}

Table 10: Status of Temporary Employment by Destinations and Size of Establishments

\begin{tabular}{|c|c|c|c|c|c|c|c|}
\hline \multirow{3}{*}{\multicolumn{2}{|c|}{ Establishment Details }} & \multicolumn{6}{|c|}{ Temporary Staff per Establishment } \\
\hline & & \multicolumn{2}{|c|}{ Male } & \multicolumn{2}{|c|}{ Female } & \multicolumn{2}{|l|}{ Total } \\
\hline & & Mean & $\begin{array}{l}\text { Std. } \\
\text { Dev }\end{array}$ & Mean & $\begin{array}{l}\text { Std. } \\
\text { Dev }\end{array}$ & Mean & Std. Dev \\
\hline \multirow{4}{*}{ Sauraha } & Small $<25$ beds & 0.19 & 0.54 & 0.19 & 0.65 & 0.39 & 0.99 \\
\hline & $\begin{array}{l}\text { Medium 26-50 } \\
\text { beds }\end{array}$ & 0.13 & 0.45 & 0.00 & 0.00 & 0.13 & 0.45 \\
\hline & Large $51+$ beds & 1.56 & 2.45 & 0.00 & 0.00 & 1.56 & 2.45 \\
\hline & Total & 0.51 & 1.41 & 0.08 & 0.43 & 0.59 & 1.49 \\
\hline \multirow{4}{*}{ Nagarkot } & Small $<25$ beds & 0.07 & 0.26 & 0.00 & 0.00 & 0.07 & 0.26 \\
\hline & $\begin{array}{l}\text { Medium 26-50 } \\
\text { beds }\end{array}$ & 0.00 & 0.00 & 0.00 & 0.00 & 0.00 & 0.00 \\
\hline & Large $51+$ beds & 0.00 & 0.00 & 0.00 & 0.00 & 0.00 & 0.00 \\
\hline & Total & 0.03 & 0.18 & 0.00 & 0.00 & 0.03 & 0.18 \\
\hline \multirow{4}{*}{ Bhaktapur } & Small $<25$ beds & 0.33 & 0.65 & 0.50 & 1.00 & 0.83 & 1.40 \\
\hline & $\begin{array}{l}\text { Medium 26-50 } \\
\text { beds }\end{array}$ & 0.00 & 0.00 & 0.00 & 0.00 & 0.00 & 0.00 \\
\hline & Large $51+$ beds & 5.00 & . & 0.00 & . & 5.00 & . \\
\hline & Total & 0.56 & 1.31 & 0.38 & 0.89 & 0.94 & 1.65 \\
\hline \multirow{4}{*}{ Total } & Small $<25$ beds & 0.19 & 0.51 & 0.21 & 0.67 & 0.40 & 0.99 \\
\hline & $\begin{array}{l}\text { Medium 26-50 } \\
\text { beds }\end{array}$ & 0.08 & 0.37 & 0.00 & 0.00 & 0.08 & 0.37 \\
\hline & Large $51+$ beds & 1.22 & 2.24 & 0.00 & 0.00 & 1.22 & 2.24 \\
\hline & Total & 0.39 & 1.21 & 0.10 & 0.47 & 0.49 & 1.33 \\
\hline
\end{tabular}


Table 10 highlights how temporary staffs are hired in this industry in the selected destinations. What can be noticed from Table 10 is that in most cases the hiring of temporary staff is almost negligible. This may be indicating that there is no system of hiring temporary staff on a large scale and even during the peak season the regular permanent staff may be sufficient to provide all the necessary services demanded by the visitors. One point that did come up during the discussion was that the permanent staffs are generally requested to take their annual time off during the slack season and may be expected to provide extra time during the peak season. This issue, however, needs to be explored in more detail. The status of total employment is provided in Table 11.

Table 11: Status of Total Employment by Destinations and Size of Establishments

\begin{tabular}{|c|c|c|c|c|c|c|c|}
\hline \multirow{3}{*}{\multicolumn{2}{|c|}{ Establishment Details }} & \multicolumn{6}{|c|}{ Total Staff (permanent + temporary) } \\
\hline & & \multicolumn{2}{|c|}{ Male } & \multicolumn{2}{|c|}{ Female } & \multicolumn{2}{|l|}{ Total } \\
\hline & & Mean & $\begin{array}{l}\text { Std. } \\
\text { Dev }\end{array}$ & Mean & $\begin{array}{l}\text { Std. } \\
\text { Dev }\end{array}$ & Mean & Std. Dev \\
\hline \multirow{4}{*}{ Sauraha } & Small $<25$ beds & 4.29 & 2.80 & 1.26 & 1.32 & 5.55 & 2.94 \\
\hline & $\begin{array}{l}\text { Medium 26-50 } \\
\text { beds }\end{array}$ & 9.29 & 4.76 & 1.54 & 1.25 & 10.83 & 5.31 \\
\hline & Large $51+$ beds & 18.94 & 8.91 & 3.22 & 2.41 & 22.17 & 10.59 \\
\hline & Total & 9.55 & 7.95 & 1.84 & 1.80 & 11.38 & 9.11 \\
\hline \multirow{4}{*}{ Nagarkot } & Small $<25$ beds & 5.40 & 1.50 & 1.13 & 0.74 & 6.53 & 1.73 \\
\hline & $\begin{array}{l}\text { Medium 26-50 } \\
\text { beds }\end{array}$ & 10.67 & 5.43 & 1.00 & 0.87 & 11.67 & 6.06 \\
\hline & Large $51+$ beds & 27.63 & 18.65 & 3.75 & 1.49 & 31.38 & 19.86 \\
\hline & Total & 12.44 & 13.10 & 1.75 & 1.52 & 14.19 & 14.36 \\
\hline \multirow{4}{*}{ Bhaktapur } & Small $<25$ beds & 2.83 & 1.64 & 1.92 & 1.51 & 4.75 & 2.96 \\
\hline & $\begin{array}{l}\text { Medium 26-50 } \\
\text { beds }\end{array}$ & 8.00 & $\mathbf{5 . 5 7}$ & 2.33 & 0.58 & 10.33 & 6.03 \\
\hline & Large $51+$ beds & 14.00 & . & 6.00 & . & 20.00 & . \\
\hline & Total & 4.50 & 4.10 & 2.25 & 1.65 & 6.75 & 5.36 \\
\hline \multirow{4}{*}{ Total } & Small $<25$ beds & 4.28 & 2.44 & 1.36 & 1.25 & 5.64 & 2.71 \\
\hline & $\begin{array}{l}\text { Medium 26-50 } \\
\text { beds }\end{array}$ & 9.53 & 4.90 & 1.47 & 1.16 & 11.00 & 5.40 \\
\hline & Large $51+$ beds & 21.33 & 12.79 & 3.48 & 2.17 & 24.81 & 14.09 \\
\hline & Total & 9.64 & 9.48 & 1.87 & 1.71 & 11.51 & 10.56 \\
\hline
\end{tabular}

From the perpective of employment, the local impact will be highest if the majority of those employed by the accommodations are local people. However, this is always not possible since the the manpower required in the establishments 
will vary depending on the different skills required and not all skills may be locally available. During the survey the respondents were asked about the number of local staff hired, number of staff hired from the periphery of the local area and from the rest of Nepal. In the case of Sauraha, for example, staffs hired could be locals from within Sauraha, then from Chitwan district and finally from outside Chitwan. However, in the case of Bhaktapur and Nagarkot there could be some overlap but the most important information this question attempts to gather is on the magnitude of the local employment. But first let us see the total employment generated by the accommodation establishments in the three destinations. This information is provided in Table 12. In total, there are 1,393 jobs provided by the establishments of which $60 \%$ are provided in Sauraha followed by 33\% in Nagarkot and about $8 \%$ in Bhaktapur. All together 1,167 (84\%) males are employed and only $226(16 \%)$ are females.

Table 12: Total Employment by Destinations

\begin{tabular}{|l|l|l|l|}
\hline \multirow{2}{*}{ Destinations } & \multicolumn{3}{|l|}{ Number of Staff } \\
\cline { 2 - 4 } & Total (\%) & Males (\%) & Females (\%) \\
\hline Sauraha & $831(60)$ & $697(84)$ & $134(16)$ \\
\hline Nagarkot & $454(33)$ & $398(88)$ & $56(12)$ \\
\hline Bhaktapur & $108(8)$ & $72(67)$ & $36(33)$ \\
\hline Total & $1393(100)$ & $1167(84)$ & $226(16)$ \\
\hline
\end{tabular}

The question on the direct employment impact of tourism can be observed from the results presented in Table 13. In total (1393), 56\% (785) of the staff hired by the industry in the destinations considered are local. Another 22\% (304) are hired from peripheral area. In other words, these two categories alone account for $78 \%$ (1089) of the jobs created by the accommodation sector in the three destinations and $21 \%$ (298) are accounted for by staff from different parts of the country. The results indicate that the accommodation sector is a good source of local employment. 
Table 13: Impact of Tourism on Local Employment

\begin{tabular}{|l|l|l|l|l|}
\hline \multirow{2}{*}{ Destinations } & \multicolumn{4}{|l|}{ Number of staffs hired } \\
\cline { 2 - 5 } & Locally & $\begin{array}{l}\text { Peripheral } \\
\text { area }\end{array}$ & $\begin{array}{l}\text { Other parts } \\
\text { of the } \\
\text { country }\end{array}$ & $\begin{array}{l}\text { Total } \\
\text { Staff }\end{array}$ \\
\hline Sauraha & $450(32)$ & $256(18)$ & $124(9)$ & $831(60)$ \\
\hline Nagarkot & $267(19)$ & $35(3)$ & $148(11)$ & $454(33)$ \\
\hline Bhaktapur & $68(5)$ & $13(1)$ & $26(2)$ & $108(8)$ \\
\hline Total & $785(56)$ & $304(22)$ & $298(21)$ & 1393 \\
\hline
\end{tabular}

Table 14: Annual Salaries Paid to Staff by Destinations and Staff Status

\begin{tabular}{|l|l|l|l|l|}
\hline \multirow{2}{*}{ Destinations } & \multicolumn{4}{|c|}{ Annual Salary Paid (in Rs) } \\
\cline { 2 - 5 } & Local Staff & $\begin{array}{l}\text { Staff from } \\
\text { Peripheral } \\
\text { Area }\end{array}$ & $\begin{array}{l}\text { Staff beyond } \\
\text { Peripheral } \\
\text { Area }\end{array}$ & Total \\
\hline \multirow{3}{*}{ Sauraha } & $37,006,128$ & $21,227,282$ & $10,046,254$ & $68,279,664$ \\
\cline { 2 - 6 } & $54 \%$ & $31 \%$ & $15 \%$ & $100 \%$ \\
\hline \multirow{3}{*}{ Nagarkot } & $22,396,296$ & $2,795,153$ & $13,859,959$ & $39,051,408$ \\
\cline { 2 - 6 } & $57 \%$ & $7 \%$ & $35 \%$ & $100 \%$ \\
\hline \multirow{3}{*}{ Bhaktapur } & $5,591,228$ & $1,004,723$ & $1,912,049$ & $8,508,000$ \\
\cline { 2 - 6 } & $66 \%$ & $12 \%$ & $22 \%$ & $100 \%$ \\
\hline Total & $64,993,651$ & $25,027,158$ & $25,818,263$ & $115,839,072$ \\
\hline
\end{tabular}

Based on the information provided by the respondents, the total salaries paid by the 121 accommodation establishments in the three destinations is about Rs 116 million per annum (US\$ 1.4 million) (last column last row). Observing the number across the rows gives an idea of the total salaries accruing to the employees in each destination. In Sauraha the accommodation establishments pay about Rs 68 million in salaries to the staff. Likewise, in Nagarkot and Bhaktapur the amounts are Rs 39 and 8 million respectively. The large difference in the salaries paid is due to the difference in the number of accommodation establishments. The number of establishments in Sauraha is 
highest (73) followed by Nagarkot (32) and Bhaktapur (16) and thus on a per establishment basis the highest salary expense is accounted by establishments in Nagarkot (Rs. 1,501,977), followed by Sauraha (Rs. 935,337) and finally Bhaktapur (Rs. 531,750). However, when the average annual salary per staff across the destination is observed, it appears to be fairly competitive - respectively Rs 82,166, Rs 86,016 and Rs 78,778 in Sauraha, Nagarkot and Bhaktapur (Table 15).

It is interesting to now examine the amount and percentage of salary that accrues to the local staff and how this compares with the other staffs from the peripheral areas and beyond. The results are provided in Table 14. In Sauraha, for example, 54\% of Rs. 68 million paid in salaries accrues to the local staff and is a significant impact. This accrual is seen to increase in Nagarkot (57\%) and even more in Bhaktapur (66\%). In Sauraha the magnitude of the salary accruing to staffs from the peripheral area is higher than the magnitude of salary accruing to staffs that are from the beyond the peripheral area.

However, in Nagarkot and Bhaktapur this is not the case and the staff from outside the magnitude of the salary accruing to the staff from the peripheral area is greater in magnitude than the salary accruing to the peripheral staff. At least in Nagarkot, the reason could be that staffs beyond the peripheral areas have relatively higher salary rate than the other staff (Table 15). In the case of Bhaktapur, the average annual salary of staff from peripheral area is relatively higher than the other two groups and higher salary expense observed in table 14 is because of the larger number of staffs in this group (beyond peripheral area see Table 13 on staff hired).

Table 15: Average Annual Salary Paid Per Staff by Area (in Rs)

\begin{tabular}{|l|l|l|l|l|}
\hline Destination & $\begin{array}{l}\text { Local } \\
\text { Staff }\end{array}$ & $\begin{array}{l}\text { Staff from } \\
\text { Peripheral Area }\end{array}$ & $\begin{array}{l}\text { Staff beyond } \\
\text { Peripheral Area }\end{array}$ & Total \\
\hline Sauraha & 82,236 & 82,919 & 81,018 & 82,166 \\
\hline Nagarkot & 83,881 & 79,862 & 93,648 & 86,016 \\
\hline Bhaktapur & 82,224 & 77,286 & 73,540 & 78,778 \\
\hline Average & 82,794 & 82,326 & 86,638 & 83,158 \\
\hline
\end{tabular}


Finally, it should be noted that the real benefits - such as both cash and kind - received by the staff is higher than the monetary/salary benefits. The $10 \%$ service charge which establishments receive from the guest is a direct cash benefit which accrues to the staff. Although we do not have any estimate on this benefit it is substantial and may be about $50 \%$ or more of the annual salary benefit.

All staffs were also reported to receive the Dashain bonus, which in most cases was a months' salary every year during the time of Dashain. Another important benefit the staffs receive is in-kind benefit, namely two meals a day and tea. Given that a simple Nepali meal (dal, bhat, tarkari and achaar) costs between Rs. 100 to 150, this benefit is also sizeable. Similarly, all the staffs also receive basic healthcare benefits. We, however, have no information on the nature and the cost associated with this benefit. Besides, many staffs are provided with uniforms, which is another additional benefit they receive from the establishments.

In the present study there is no way we can estimate the full extent of benefits received by the employees in the accommodation establishments, but the available information leads us to conclude that the benefits are fairly good and much more than the cash benefits reported as salaries. In another research study, it will be interesting to value all the above benefits to estimate the full benefits employees receive in the tourism industry. This is to say these are direct benefits in terms of salaries and the direct and induced benefits from tourism in the destinations are not accounted for.

\section{Annual Expenses by Accommodation Establishments}

The study also made an attempt to collect information on the annual food and non-food expenses made by the establishments using recall method. Although the information provided may not be very accurate, it nevertheless will shed light on how the major expenditures of the establishments are distributed across different areas. In addition, it will also shed light on identifying 
some possibilities of the development of micro enterprises in the local areas.

For simplicity, we categorized all monthly purchases made by the establishments into five food groups and one non-food group. There was a variety of information collected on the food types before forming the group. Information on non-food was collected for the full year.

The food section was more detailed but only major food items were considered. Also respondents were asked from which area (local, peripheral and beyond peripheral area) they purchased the food items. This information is useful for identifying the sources of food purchased by the establishments, which then becomes useful to scope the possibilities of the development of micro enterprises in the local areas. The five food groups considered are cereals and dairy (milk, bread, flour, noodles, rice, daal, eggs, and spices), vegetables and oils, meats (fish, chicken, buff and pork), beverages (soft drinks, mineral water and water jars, beer etc) and other foods.

For this part of the analysis we first note that the information on food and non-food expenses is summed across all destinations. The idea is to identify the distribution of expenses across major food items and across the locations so as to give an idea of the percentage of expenses that is retained (Table 16). The estimate indicates that the 121 establishments in the three destinations spend annually Rs. 219 million (US\$ 2.6 million) on major food items annually. Of this amount, in aggregate only Rs. 47 million is retained locally, which is about $22 \%$ of the total food expenses made by the 121 establishments. Food purchase made from the peripheral area is high $(68 \%)$ indicating that nearby people are also able to capture a high percentage of benefits by selling food items to the tourism sector in their areas. The results indicate that only about $14 \%$ of the expenses actually go beyond the peripheral area.

Among the food groups expense on beverage is the highest (Rs 79 million). The result on the beverage expenses is totally in 
contrast to that of vegetables, where the local retention is the lowest (12\% within food group) and also as percentage (4\%) of total expenses on all foods. The retention of expenses on beverages in the peripheral area within the food group is high (54\%) and across all food groups it is $19 \%$. The high expense accruing to peripheral areas is because there are many bottling plants near the destinations. There is almost no possibly to increase the retention of this benefit in the local area and establishments will continue to have to rely on obtaining their beverage supplies from either the peripheral areas or beyond.

Expense on meats (Rs. 65 million) is second only to the expenses on beverages. The establishments appear to rely heavily on the peripheral areas for meat purchases and spend Rs. 50 million (77\%). In contrast, the local purchase of meat is only Rs. 14 million (22\%) or about $28 \%$ of the peripheral expenses on meat. Purchase of meat from outside areas is almost negligible.

Examining the expenses on the food groups it is noticed that local retention is highest (31\%) among the vegetables and oils and other food groups. Within the last several decades many rural areas of Nepal that are adjacent to popular tourist destinations such as the ones considered for this study have begun vegetable production and are able to sell to the accommodation establishments. Interestingly, the establishments remarked that the local supply of vegetables is still inadequate and as a result they are forced to buy from the peripheral areas. Hence, the expenses in the peripheral areas on vegetables are almost double the amount spent in the local area. Because of the perishable nature of vegetables, its purchase beyond the peripheral area is low (3\%) as expected. Across all food expanses the percentage spent on vegetables is almost one fifth $(22 \%)$.

The expense on the cereal food group is about Rs. 18 million and is about $8 \%$ of the total expenses on food. Local purchase of cereal is also relatively low for several reasons. Most establishments prefer processed items which are often not 
available locally, and if available, the supplies may be low. As a result local retention of the expenses in cereal group is only $17 \%$ with $76 \%$ expenses being captured by the peripheral areas.

Finally, the expense on non-food items is a small percentage (19\%) of the total expenses (Rs. 269 million) made by the establishments as shown in the last column of Table 15. This depicts that most of the expenses made on the food items by the establishments actually go to the peripheral areas (55\% or Rs. 149 million).

The result clearly indicates that local areas adjacent to tourism destinations appear to have a comparative advantage in vegetable production and should gradually move to specialize in this activity. There is also scope to develop poultry to supply larger amount of fresh chicken meat and eggs.

Table 16: Annual Expenditure Reported by Accommodation Establishment in Selected Destination by Type of Expenditure and Area of Purchase

\begin{tabular}{|c|c|c|c|c|c|}
\hline \multirow{2}{*}{\multicolumn{2}{|c|}{$\begin{array}{l}\text { Type of Food and } \\
\text { Purchase Area }\end{array}$}} & \multirow{3}{*}{$\begin{array}{l}\text { Total } \\
\text { (Rs in } \\
\text { 'millions') } \\
3,185\end{array}$} & \multicolumn{3}{|l|}{ As $\%$ of } \\
\hline & & & \multirow{2}{*}{$\begin{array}{l}\text { Total } \\
\text { Food } \\
\text { Group } \\
\text { Expense } \\
17.48\end{array}$} & \multirow{2}{*}{$\begin{array}{l}\text { Total } \\
\text { Food } \\
\text { Expense } \\
1.46\end{array}$} & \multirow{2}{*}{$\begin{array}{l}\text { Total } \\
\text { Food }+ \\
\text { Nonfood } \\
\text { Expense } \\
1.19\end{array}$} \\
\hline \multirow{4}{*}{ 怤 } & Local & & & & \\
\hline & $\begin{array}{l}\text { Peripheral } \\
\text { Area }\end{array}$ & 13,891 & 76.23 & 6.36 & 5.17 \\
\hline & $\begin{array}{l}\text { Beyond } \\
\text { Peripheral } \\
\text { Area }\end{array}$ & 1,146 & 6.29 & 0.52 & 0.43 \\
\hline & Total & 18,222 & 100.00 & 8.35 & 6.78 \\
\hline \multirow{4}{*}{ 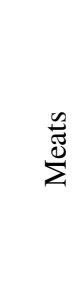 } & Local & 14,144 & 21.63 & 6.48 & 5.27 \\
\hline & $\begin{array}{l}\text { Peripheral } \\
\text { Area }\end{array}$ & 50,360 & 77.01 & 23.07 & 18.75 \\
\hline & $\begin{array}{l}\text { Beyond } \\
\text { Peripheral } \\
\text { Area }\end{array}$ & 887 & 1.36 & 0.41 & 0.33 \\
\hline & Total & 65,391 & 100.00 & 29.96 & 24.34 \\
\hline
\end{tabular}




\begin{tabular}{|c|c|c|c|c|c|}
\hline \multirow{4}{*}{ 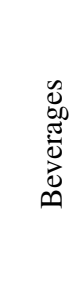 } & Local & 9,772 & 12.41 & 4.48 & 3.64 \\
\hline & $\begin{array}{l}\text { Peripheral } \\
\text { Area }\end{array}$ & 42,192 & 53.60 & 19.33 & 15.71 \\
\hline & $\begin{array}{l}\text { Beyond } \\
\text { Peripheral } \\
\text { Area }\end{array}$ & 26,753 & 33.99 & 12.26 & 9.96 \\
\hline & Total & 78,717 & 100.00 & 36.06 & 29.30 \\
\hline \multirow{4}{*}{ 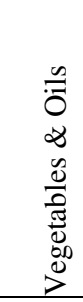 } & Local & 14,985 & 30.52 & 6.86 & 5.58 \\
\hline & $\begin{array}{l}\text { Peripheral } \\
\text { Area }\end{array}$ & 32,975 & 67.17 & 15.11 & 12.28 \\
\hline & $\begin{array}{l}\text { Beyond } \\
\text { Peripheral } \\
\text { Area }\end{array}$ & 1,131 & 2.30 & 0.52 & 0.42 \\
\hline & Total & 49,090 & 100.00 & 22.49 & 18.27 \\
\hline \multirow{4}{*}{$\begin{array}{l}0 \\
0 \\
0 \\
\stackrel{0}{0} \\
\stackrel{5}{0}\end{array}$} & Local & 4,477 & 31.37 & 2.05 & 1.67 \\
\hline & $\begin{array}{l}\text { Peripheral } \\
\text { Area }\end{array}$ & 9,391 & 65.79 & 4.30 & 3.50 \\
\hline & $\begin{array}{l}\text { Beyond } \\
\text { Peripheral } \\
\text { Area }\end{array}$ & 406 & 2.84 & 0.19 & 0.15 \\
\hline & Total & 14,274 & 100.00 & 6.54 & 5.31 \\
\hline \multirow{4}{*}{$\begin{array}{l}\overrightarrow{0} \\
\stackrel{0}{0} \\
\stackrel{\pi}{0} \\
0\end{array}$} & Local & 46,937 & 21.50 & 21.50 & 17.47 \\
\hline & $\begin{array}{l}\text { Peripheral } \\
\text { Area }\end{array}$ & 148,808 & 68.17 & 68.17 & 55.40 \\
\hline & $\begin{array}{l}\text { Beyond } \\
\text { Peripheral } \\
\text { Area }\end{array}$ & 30,322 & 13.89 & 13.89 & 11.29 \\
\hline & Total & 218,296 & 100.00 & 100.00 & 81.26 \\
\hline \multicolumn{2}{|c|}{$\begin{array}{l}\text { Annual Non Food } \\
\text { Purchase Total }\end{array}$} & 50,330 & - & - & 18.74 \\
\hline \multicolumn{2}{|c|}{ All Total } & 268,626 & - & - & 100.00 \\
\hline
\end{tabular}

\section{Summary}

It was found that older establishments in general were larger in terms of their capacities (beds and rooms) indicating that experience is positively associated with higher investment risks. The average length of stay in a destination varied. In both Bhaktapur and Nagarkot, which are overnight stay destinations, 
the length of stay is lower (1.6 days) than in Sauraha (3 -9 days), where in the later destination besides more travel-time there are more activities to enjoy as well.

Across the destinations, all lodges in Nagarkot and Bhaktapur reported they reduce their tariff rates. While the variation in the tariff rates across establishments was found to be statistically significant, the variations across destinations was, however, not significant. Hotels in Sauraha appear to do the best as only $39 \%$ reported reducing tariff rates in the slack season. Overall, the results indicate that guest houses have a relatively greater problem of occupancy in the slack season and, as a result, majority $(84 \%)$ of the guest houses reduce their tariff rates. On the other hand, the hotels face a relatively fewer problems since only $52 \%$ of them reported to reduce tariff rates in the slack season. No establishment reported any loss.

The larger establishments obviously hired more staffs than either the medium or small size establishments with 11 staffs being the average permanent employees per establishment, which is fairly uniform across the establishments (standard deviation 10.4) indicating that permanent employment is directly proportional to the size of establishment. The tourism industry in the destinations covered is dominated by male staffs (average 9.3), which is over five times higher than female employment (average 1.8). In all establishments the percentage of females employed relative to men was found to be poor, except in Bhaktapur where female permanent employment is relatively higher (about 32\%) than in the other two destinations. It was also observed that establishments do not tend to hire too many extra staffs during the peak season.

Overall, the accommodation sector is a good source of employment. The survey shows that 1,393 jobs were provided by the establishments of which $60 \%$ were in Sauraha followed by Nagarkot (33\%) and Bhaktapur (8\%). Of these 1,167 (84\%) were males and only $226(16 \%)$ females. Majority of the hired persons were from local areas $56 \%$ and $22 \%$ from peripheral/nearby areas. In other words, these two categories 
alone account for $78 \%$ (1089) of the jobs created by the accommodations in the three destinations, and $21 \%$ (298) are accounted for by staffs from different parts of the country.

The salaries paid by the establishments to the staff amounted to about Rs 116 million per annum (US\$ 1.4 million). The highest was paid in Sauraha (Rs. 68 million) followed by Nagarkot (Rs 39 million) and Bhaktapur (Rs. 8 million), respectively and reflects the number of establishments in these destinations Sauraha (73) Nagarkot (32) and Bhaktapur (16). The average annual salary per staff across the destinations was estimated to be fairly competitive and was respectively Rs. 82,166, Rs. 86,016 and Rs. 78,778 in Sauraha, Nagarkot and Bhaktapur. Salaries paid to the local staff accounted for 54\%, 57\% and $66 \%$ in Sauraha, Nagarkot and Bhaktapur, respectively. Other tangible benefits the staff received are from $10 \%$ service charge paid by guests, the Dasai bonus, two meals a day and tea, basic healthcare benefits and in some cases uniforms.

Another local impact of the establishment was judged by the amount of expenditures on the food and non-food items. The 121 establishments in the three destinations were estimated to spend annually Rs. 219 million (US\$ 2.6 million) on major food items. Of this amount, about Rs. 47 million (22\%) was retained locally and expenses on food items in the peripheral area was highest (68\%). This result indicates that there is a fairly good linkage between the tourism sector and the local economy in all the destinations, especially when it comes to local food production and its purchase by the establishments.

Most of the expenditure made by the establishments on beverages accrues to businesses that are outside the local and peripheral areas. The expense on meats (Rs. 65 million) is second only to the expenses on beverages. The establishments appear to rely heavily on the peripheral areas for meat purchases and spend Rs. 50 million (77\%). Expenses on vegetables (perishable product) originating from the local areas is high (31\%). Interestingly, the establishments remarked that the local supply of vegetables is still inadequate and as a result 
they are forced to buy from the peripheral areas. The expense on non-food items is a small percentage $(19 \%)$ of the total expenses (Rs 269 million) made by the establishments and most of it actually goes to the peripheral areas (55\% or Rs 149 million).

The establishments are making good business in the three destinations given that the reported occupancy rate is over $40 \%$ during the slack season and over $90 \%$ during the peak season. Majority of the bigger accommodation establishments have higher occupancy rate even than smaller ones, and in Bhaktapur the slack season occupancy rate of lodges is low (15\%). This relatively higher occupancy rate during the slack season reflects that the bigger accommodation establishments have good link with tours and travels operators. Secondly, the larger establishments also reduce tariff rates during the slack seasons to attract visitors.

\section{Conclusions}

Tourism cannot provide employment and income to all the people in a destination and hence it cannot be a panacea for economic development. But where there are potentials to develop this sector, there is scope to provide opportunities to a larger number of people, given its labor intensive nature (Ashley et al, 2007; Banskota and Sharma, 1996). The result clearly indicates local areas adjacent to tourism destinations appear to have a comparative advantage in vegetable production and should gradually move to specialize in this activity. There is also scope to develop the livestock industry to supply larger quantities of fresh meat and eggs.

Although not examined by the present study, it can be said that tourism can also provide income and employment opportunities in other sectors e.g., public transport, wildlife safari, elephant rides, tour guides, restaurants, furniture, and various types of shops etc. In many places local people are able to perform cultural shows, and besides earning incomes some are able to promote their local culture as well. This is especially true in 
Sauraha, where the Tharu communities perform traditional dances in their native costumes to the tourists and earn incomes.

It is argued that tourism employs a relatively high proportion of women and thus contributes to gender equality. However, such was not the case in the three destinations. The percentage of females' employment was significantly lower than of the males (Ashley et al, 2007).

Tourism can help the poor improve their livelihoods, but this will require concerted efforts - strategies that help establish strong linkages with the tourism sector (Banskota and Sharma, 1996). For example, there is scope to involve the poor in vegetable production in the destinations considered, as the establishments reported inadequate supply of vegetables from local areas. Scope also exists to provide more training to local people so that they are able to get better paid jobs. Overall, the study results clearly indicate that tourism contributes to the local economy providing direct employment and indirectly by purchasing food and nonfood items from local producers.

\section{References}

Afram, G.G and A.S. Del Pero. (2012). Nepal investment climate: Leveraging the private sector for job creation and growth, direction in development private sector development. Washington DC: World Bank.

Ashley, Caroline, De brine, Peter, Lehr, Amy, and White, Hannah. (2007). The role of the tourism sector in expanding economic opportunity. In Corporate Social Responsibility Initiaitve Report No. 23. Cambridge, MA: Kenndey School of Government.

Banskota, K., and Sharma, B. (1993). Performance of the tourism sector: Economic and environmental development planning for Bagmati zone. Kathmandu: ICIMOD.

Banskota, K and Sharma, B. (1995). Tourism for mountain community development: Case Study report on the Annapurna and Gorkha regions of Nepal. Kathmandu: 
International Centre for Integrated Mountain Development (ICIMOD), Centre for Environment and Resource Studies (CREST).

Bista, Raghu. (2009). Tourism policy, possibilities and destination service management in Nepal. Thesis submitted for the Doctor of Philosophy at the University of Macedonia, Economic and Social Sciences, Department of Applied Informatics, Thessaloniki, Greece.

Enterprise Europe Network, 2006-2007. Nepal tourism sector analysis. Asia Invest Programme, European Union.

Frechtling, D. (2006). An assessment of visitor expenditure methods and models. Journal of Travel Research, 20, $1-10$.

Frechtling, D. (2011). Exploring the full economic impact of tourism for policy making. Madrid: World Tourism Organization..

Ministry of Tourism and Civil Aviation (MOTCA). (2011). Nepal Tourism Statistics 2011. Kathmandu: Government of Nepal.

MoTCA. (2009). Tourism Vision 2020. Kathmandu: Ministry of Tourism and Civil Aviation, Government of Nepal.

Roe, Caroline Ashley, Page, Sheila, and Meyer, Dorothea. (2004, March). Tourism and the poor: Analysing and interpreting tourism: Statistics from a poverty perspective. PPT Working Paper No. 16. PPT Partnership London.

Shah, Kishore, and Gupta, Vasanti. (2000, April). Tourism, the poor and other stakeholders: Experience in Asia. Fair Trade in Tourism. Tourism Concern / UNL / VSO, Overseas Development Institute.

Subedi, C.R. (2011). Tourist accommodation facilities in the major tourist areas of Nepal. Nepal Tourism and Development Review, 1, 101-123.

Wang, Ying, and Davidson, Michael C. (2010). A review of micro-analyses of tourist expenditure. Current Issues in Tourism, 13 (6), 507-524. 